NBER WORKING PAPER SERIES

\title{
TESTING STATIC TRADE-OFF AGAINST PECKING ORDER MODELS \\ OF CAPITAL STRUCTURE
}

\author{
Lakshmi Shyam-Sunder \\ Stewart C. Myers
}

Working Paper No. 4722

\section{NATIONAL BUREAU OF ECONOMIC RESEARCH \\ 1050 Massachusetts Avenue \\ Cambridge, MA 02138 \\ April 1994}

This paper is part of NBER's research program in Corporate Finance. Any opinions expressed are those of the authors and not those of the National Bureau of Economic Research. 


\title{
TESTING STATIC TRADE-OFF \\ AGAINST PECKING ORDER MODELS \\ OF CAPITAL STRUCTURE
}

\begin{abstract}
This paper tests traditional capital structure models against the alternative of a pecking order model of corporate financing. The basic pecking order model, which predicts external debt financing driven by the internal financial deficit, has much greater explanatory power than a static trade-off model which predicts that each firm adjusts toward an optimal debt ratio. We show that the power of some usual tests of the trade-off model is virtually nil. We question whether the available empirical evidence supports the notion of an optimal debt ratio.
\end{abstract}

Lakshmi Shyam-Sunder Sloan School of Management MIT 50 Memorial Drive Cambridge, MA 02139
Stewart C. Myers

Sloan School of Management MIT

50 Memorial Drive

Cambridge, MA 02139

and NBER 


\section{Testing Static Trade-off against Pecking Order Models of Capital Structure}

\section{Introduction}

The theory of capital structure has been dominated by the search for optimal capital structure. Optimums normally require a trade-off, in this case between the tax advantages of borrowed money and the costs of financial distress when the firm finds it has borrowed too much. A value-maximizing firm would equate this benefit and cost at the margin, and operate at the top of the curve in Figure 1. The curve would top out at relatively high debt ratios for safe, profitable firms with plenty of taxes to shield and assets whose values would escape serious damage in financial distress. This static trade-off theory quickly translates to empirical hypotheses. For example, it predicts reversion of the actual debt ratio towards a target or optimum, and it predicts a cross-sectional relationship between average debt ratios and asset risk, profitability, tax status and asset type.

Several pounds of empirical literature have been guided by such hypotheses. Most of these studies have supported the static trade-off theory. That is, they have rejected the null, and shown some statistically significant coefficients consistent with the theory. However, none of these papers has systematically compared the explanatory power of their fitted equations with altemative explanations of financing behavior, and none has checked whether their equations could seem to work even when actual financing is driven by other forces. That is, they have not checked the power of their tests against alternative hypotheses.

This paper puts static trade-off and pecking order theories of capital structure on the track together. In the pecking order theory, there is no well-defined optimal capital structure. The attraction of interest tax shields and the threat of financial distress are assumed second order. Debt ratios change when there is an imbalance of internal cash flow, net of dividends, and real investment opportunities. Highly profitable firms with limited investment opportunities work down to low debt ratios. Firms whose investment opportunities outrun internally generated funds borrow more and more. Changes in debt 
ratios are driven by the need for external funds, not by any attempt to reach an optimal capital structure.

This simple pecking order story is easily "disproved" every time a company that could issue investment-grade debt issues stock instead. Yet we find that it explains much more of the variance in actual debt ratios than the static trade-off specifications. Moreover, we show that the pecking order hypothesis can be rejected if actual financing follows the static tradeoff story. On the other hand, the usual specification of the static trade-off hypothesis will appear to work when financing follows the pecking order. Thus we have power to reject the pecking order but not the static trade-off specification. We conclude that the pecking order is a much better first-cut explanation of the debt-equity choice, and we question the evidence for the notion of an optimal debt ratio.

\section{Prior work}

Now we back off a bit and admit some evidence in favor of the static trade-off and optimal capital structure. Several authors, such as Schwartz and Aronson (1967), have documented evidence of strong industry effects in debt ratios which they interpret as evidence of optimal ratios. Long and Malitz (1985) show that leverage ratios are negatively related to research and development expenditures which they use as a proxy for intangible assets, and Mackie-Mason (1991) reports evidence that firms with tax loss carry forwards are less likely to issue debt ${ }^{1}$. This follows Miller and Modigliani (1966), who detected the positive effects of interest tax shields in the market values of electric utilities.

Bradley, Jarrell and Kim (1984) give an excellent review and synthesis of some of the earlier theoretical and empirical literature on optimal capital structure and conclude that their findings "support the modern balancing [trade-off] theory of capital structure." More recently, however, Titman and Wessels (1988), using a latent variables approach, have found only mixed evidence for the role of the factors predicted by the static trade-off theory.

Other studies provide more direct evidence that firms adjust toward a target debt ratio. Taggart (1977), Marsh (1982), Auerbach (1984) and Jalilvand and Harris (1984) find mean reversion in debt ratios and show that firms appear to adjust toward a debt target. Marsh, using a logit model, finds that the probabilities of debt and equity issues vary with

\footnotetext{
${ }^{1}$ Smith and Watts (1992) also document a negative relationship belween growth opportunitles and debt ratios.
} 
the deviation of the current debt ratio from the target, which he estimates as the observed average over his sample period. Using similar proxies for the target, Taggart and Jalilvand-Harris estimate partial adjustment models and find significant adjustment coefficients which they interpret as evidence of firms optimizing their debt ratios. Auerbach also estimates a target adjustment model but allows for firm-specific and time varying targets. He also interprets the significant adjustment coefficients as support for target adjustment behavior.

However, other evidence is inconsistent with the optimal debt ratios or can be interpreted differently. First, as pointed out by Myers (1984), the negative valuation effects of equity issues or leverage reducing exchange offers - see Masulis (1980) - do not support the trade-off story. If changes in debt ratios are movements towards the top of the curve (in Figure 1), both increases and decreases in leverage should be value enhancing. 2 Second, Kester (1986), Titman and Wessels (1988) and Rajan and Zingales (1994) find strong negative relationships between debt ratios and past profitability. Models based on the trade-off of the benefits of debt and the costs of financial distress predict a positive relationship. 3

This empirical literature has been guided almost exclusively, though sometimes implicitly, by the assumption of an optimal debt ratio. In Myers's (1984) and Myers and Majluf's (1984) pecking order model there is no optimal debt ratio. ${ }^{4}$ Instead, because of asymmetric information and signalling problems associated with external funding, firms' financing policies follow a hierarchy, with a preference for internal over external finance, and for debt over equity. A strict interpretation of this model suggests that firms do not aim at any target debt ratio; rather, the debt ratio is just the cumulative result of hierarchical

2 Jensen (1986) suggests an alternative framework to explain this and other evidence on valuation effects of various transactions. However, Jensen's analysis relies on an agency cost and control-related motivation that is not examined in this paper. The valuation effects of leverage-altering transactions could also be viewed as an information effect of the kind proposed by Ross (1977), in which a decline in profitability would lead to lower debt ratlos and send a disappointing signal about future profitability.

3 This result could be explained in a trade-off framework if high (low) past profitability. Is viewed as a proxy for higher (lower) future growth opportunities, which are intangible assets that could be severely damaged in financial distress. However, other variables such as lagged $q$ ratios that could arguably capture future growth options more directly are not found to be as strongly significant as past profitability. See for example, Baskin (1985).

4 Other implications of the model relating to the valuation effects of debt and equity have been tested. See for example, Asquith and Mullins (1986), Eckbo (1986), ShyamSunder (1991) and, for a review, Harris and Raviv (1991). 
financing over time. Firms that face a financial deficit will first resort to debt and such firms will be observed later as having higher debt ratios. This line of reasoning could easily explain the negative relationship between past profitability and debt ratios.

A growing literature considers liquidity constraints on real investment as a result of the asymmetric information problems of external equity financing. See for example, Hoshi, Kashyap and Scharfstein (1991), Fazzari, Hubbard and Petersen (1988) and Whited (1992). In this paper, we take real investment as exogenous, because our sample consists of large, public firms, mostly investment grade, most of which should have easy access to the debt market. These firms should be high enough on the pecking order to escape liquidity constraints due to asymmetric information.

What if our firms have excess debt capacity but systematically operate below their optimal debt ratio? This could explain why they issue debt when they need external funds. However, if they are constantly below their target over a 20 -year sample period, the concept of an optimal debt ratio has little operational meaning. On the other hand, if many such firms were found to issue equity, the pecking order would be rejected.

This paper reexamines some of the earlier evidence on target debt ratios in the light of these two contending views of corporate financing. Note, however, that both views assume shareholder wealth maximization as the corporate objective. We do not attempt to test any theory based on managerial or organizational objectives, as might be developed from Jensen (1986). Such a theory might predict behavior similar to the pecking order.

We find strong support for the pecking order prediction that firms resort (almost) exclusively to debt when there is a financial deficit. Furthermore, it demonstrates that some target adjustment models appear to work even when firms are following a pure pecking order model of financing, and therefore that the usual tests of the static trade-off theory lack power. However, our tests can correctly reject the pecking order when it is false.

The remainder of this paper is organized as follows. Section 2 defines simple specifications of the two contending hypotheses. The data, basic tests and results are described in Section 3. Section 4 shows that the power of standard target adjustment models is low. We also show that our specification of the pecking order model does not suffer from this limitation. This section also investigates the robustness of the basic models. Section 5 concludes the paper and discusses its implications for future research. 


\section{Two Simple Models}

The pecking order

In its simplest form, the pecking order model of corporate financing says that when a firm's internal cash flows are inadequate for its real investment and dividend commitments, the firm issues debt. Equity is never issued, except possibly when the firm can only issue junk debt and costs of financial distress are high.

Define:

$\mathrm{C}_{\mathrm{t}}=$ Operating cash flows, after interest and taxes

$\mathrm{DIV}_{\mathrm{t}}=$ Dividend payments

$\mathrm{X}_{\mathrm{t}}=$ Capital expenditures

$\Delta W_{t}=$ Net increase in working capital

$\mathbf{R}_{\mathbf{t}}=$ Current portion of long-term debt at start of period 5

$D_{\mathrm{t}}=$ Long-term debt outstanding

$A_{t}=$ Net book assets, including net working capital6

$d_{t}=D_{t} / A_{t}$, the book debt ratio

with all stock variables defined at the end of period t. The funds flow deficit is:

$$
D E F_{t}=\left[D I V_{t}+X_{t}+\Delta W_{t}+R_{t}-C_{t}\right]
$$

In the strict pecking onder model all components of the deficit are exogenous as long as safe debt can be issued. There is no incentive to move down the pecking order and issue stock.

The hypothesis to be tested is:

$$
\Delta D_{i t}=a+b D E F_{i t}+e_{i t}
$$

5 We assume this amount has to be repaid during period $t$.

${ }^{6}$ Alternatively, net total book assets less current liabilities. We are modelling longterm financing. 
where $\Delta D_{t}$ is the amount of debt issued -- or retired, if $D E F_{t}$ is negative -- by firm $i$. We expect $a=0$ and $b=1$.

Equation (2) is not an accounting identity because $\mathrm{DEF}_{\mathrm{t}}$ does not include equity issues or repurchases. The simple pecking order predicts that the firm will not issue or retire equity except as a "last resort."

\section{Asymmetric information and the pecking order}

The pecking order is one implication of the Myers-Majluf (1984) analysis of how asymmetric information affects investment and financing decisions. That analysis has two main results.

1. If costs of financial distress are ignored, the firm will finance real investment by issuing the safest security it can. Here "safe" means "not affected by revelation of managers' inside information." In practice this means that firms which can issue investment-grade debt will do so rather than issue equity. ${ }^{7}$

2. If costs of financial distress are serious, the firm will consider issuing equity to finance real investment or pay down debt. It may forego the issue if managers' information is sufficiently favorable and the issue price too low. In that case the debt ratio will remain uncomfortably high or real investment will be curtailed. However, less optimistic managers will go ahead and issue equity.

Thus a broader pecking order hypothesis would accommodate some equity issues. It will be difficult to distinguish pecking order and static trade-off predictions at high debt levels, and we do not attempt to do so in this paper. However, the possibility of equity issues under a more general pecking order stacks the deck against the stripped-down model tested in this paper. Equity issues at high debt levels will improve the fit of trade-off models and degrade the fit of our simple pecking order specification.

The Myers-Majluf reasoning works in reverse when the company has a surplus $\left(D E F_{t}<0\right)$ and wants to return cash to investors. ${ }^{8}$ If there are tax or other costs of holding excess funds or paying them out as cash dividends, there is a motive to repurchase shares or pay down debt. Managers who are less optimistic than investors naturally prefer to pay

\footnotetext{
7 We know that investment-grade debt is safe, in the Myers-Majluf sense, because issuing it has, on average, no stock price effects. See Shyam-Sunder (1991).

${ }^{8}$ Compare the following discussion with their Section 3.3, pp. 207-209.
} 
down debt rather than repurchasing shares at too high a price. That means that the more optimistic managers, who are inclined to repurchase, force up stock prices if they try to do so. Relative to these stock prices, the group of optimistic managers shrinks, and the stock price impact of an attempted repurchase increases. If information asymmetry is the only imperfection, the repurchase price is so high that all managers end up paying down debt.

Thus the simple pecking order's predictions do not depend on the sign of $\mathrm{DEF}_{\mathrm{t}}$. In principle the firm could become a net lender if funds surpluses persist. Of course share repurchases could occur in a Myers-Majluf model if there are significant tax or other costs of operating at a very low or negative debt ratio. Again, this stacks the deck against the stripped-down pecking-order specification.

\section{A target adjustment model}

The static trade-off theory has managers seeking optimal capital structure. Random events would bump them away from it, and they would then have to work gradually back. If the optimum debt ratio is constant, we would see mean-reverting behavior.

The simple form of the target adjustment model states that changes in the debt ratio are explained by deviations of the current ratio from the target. The regression specification is:

$$
\Delta D_{i t}=a+b\left(D_{i t}^{*}-D_{i t-1}\right)+c_{i t}
$$

where $\mathrm{D}_{\mathrm{it}}{ }^{*}$ is the target debt level for firm $\mathrm{i}$ at time $\mathrm{t}$. We take $\mathrm{b}$ as a sample-wide constant. The hypothesis to be tested is: $b>0$, indicating adjustment towards the target, but also $b<1$, implying positive adjustment costs.

Unfortunately the target is unobservable. One common response starts with the historical mean of the debt ratio for each firm, which can be multiplied by total capital to 
obtain an estimated target debt level. Altemative specifications include a rolling target for each firm using only historical information and an adjustment process that involves a lag of more than one year. Jalilvand and Harris (1984) report that use of a three-year moving average does not alter their results.

Target adjustment models predict changes in debt ratios, which depend on the net amount of debt issued. The pecking order predicts gross debt issues, because the current portion of long-term debt is a required use of funds and therefore included in DEF However, we can recast the pecking order as a predictor of net debt issues and changes in the debt ratio. These and other altemative specifications are described below.

\section{Basic Tests}

\section{Sample and data}

Our initial sample consisted of all firms on the Industrial Compustat files. Financial firms and regulated utilities were excluded. Firms are included in the final sample if they have no gaps in data on the relevant funds flow and balance sheet variables described above and if they are not involved in a "major merger" as defined in the Compustat footnotes. 9 Our requirement for continuous data follows previous tests of target adjustment models; ${ }^{10}$ tests of pecking order models only would not require continuous data.

Compustat includes a flow of funds statement from 1971. This defines the starting point of our sample period, which extends to 1989. The requirement for continuous data on flow of funds (which is necessary for our simulation tests) restricts our sample to 157 firms. ${ }^{11}$ This procedure may bias our sample toward relatively large firms with

\footnotetext{
${ }^{9}$ Major mergers often trigger major, discontinuous shifts in capital structure, but neither of the theories tested in this paper accommodate mergers undertaken in order to change capital structure. Thus we excluded firms with major mergers from the sample. 10Jalilvand and Harris (1984), Titman and Wessels (1988) and Auerbach (1985) eliminated companies for which continuous data were not available.

11 Constructing funds flow statements using changes in balance sheets proved to be beyond the reach of this paper because of inconsistencies in the reported data. Reconciling year-10-year statements was extremely difficult. We opted for a smaller sample for which data are more readily available.
} 
conservative debt ratios (since small firms with unconservative debt ratios could be more likely to drop out of the sample).

This bias, if it exists, does not affect the pecking order tests. The simple pecking order predicts the same financing behavior at all except the highest debt ratios. However, such a bias might work against the target adjustment specification of the static trade-off hypotheses. If firms in the sample are generally below their optimal debt ratios -- on the left of Figure 1 -- then their debt ratios should systematically increase in sample period and not necessarily revert to the firms' time-series averages. We could find a positive constant and a poor fit in Eq. (3).

However, we have 19 years' data for each firm in our sample. The fitted coefficients of the target adjustment models (reported below) seem to imply rapid movement toward optimal capital structure. If firms languish for many years below their optimal debt ratios, the static trade-off model can't have much practical relevance.

The analysis in this paper is restricted to book debt amounts and to book debt ratios, defined as the ratio of long-term debt to the book value of assets. As Myers (1977) has pointed out, there are rational reasons for managers to specify debt targets in terms of book values. The mean value of the book debt ratio for the 157 firms over 1971 to 1989 is .18 with a standard deviation of .16 and a maximum of .82 . Table 1 summarizes other characteristics of the sample.

\section{Results}

Panel A of Table 2 summarizes the basic OLS tests. The dependent variables are net and gross debt issued, scaled by book assets, and the change in the debt ratio. ${ }^{12}$ Results for the basic target adjustment model are given in the first and fifth columns. As in Auerbach and Jalilvand-Harris, we find constants close to zero ${ }^{13}$ and significant

Some of the problems associated with the use of Compustat data are well known --see for example, Drtina and Largay (1985). However, such errors are unlikely to obscure the first order effects that this paper addresses. Indeed, our main points with regard to the relative power of the tests (described below) can be made with simulated data. See Shyam-Sunder (1988).

${ }^{12}$ Since we are concerned with long-term financing, the denominator of the debt ratio is lotal book capitalization, that is net long-term book assets plus net working capital. Net and gross debt issues are scaled by book assets simply as a precaution against heteroscedasticity.

13This suggests that our sample is not blased towards firms operating below their optimal debt ratios for most of the sample period. If there were such a sample bias, then, 
adjustment coefficients of .33 (Column 1) and .41 (Column 5). The target is based on sample mean debt ratios for each firm. $\mathrm{R}^{2}$ s for the two specifications are .21 and .25 respectively. However, when the target is based on a three or five-year rolling average of the book debt ratio up to the preceding year, the adjustment coefficients are not significant. These results are not reported.

Panel A's even-numbered columns give results for the simple pecking order. The results for gross debt issues (fourth column) are the most pertinent. The coefficient is .85 , which is the right order of magnitude but significantly less than the simple pecking order prediction of 1.0 . The $\mathrm{R}^{2}$ is very high (.86). Considering the simplicity of the model, the pecking order does very well.

The pecking order results support the stylized fact -- evident in macroeconomic data -that external funding is dominated by debt. We document the result at the firm level. Indeed, for many individual firms, the $\mathrm{R}^{2}$ and the coefficient estimates are exactly, or very close to, 1.0. Figures $2 \mathrm{a}$ and $2 \mathrm{~b}$ show the firmwise distribution of $\mathrm{R}^{2}$ for the simple pecking order model, fitted separately to each firm over two periods, 1971-84 and 197189. Comparison of these two histograms hints that the pecking order hypothesis did less well in the last half of the 1980 s. However, several of the low $R^{2} s$ in Figure $2 b$ are for firms which undertook leveraged restructurings.

Panel A's third and seventh columns show what happens when the financing deficit and the target adjustment mechanism are included in the same equation. The target adjustment coefficients drop to less than a third of the values in column one, and significance is reduced. The magnitude and significance of the coefficients for the financing deficit are basically unchanged.

We reran all of the tests in Panel A of Table 2 involving gross and net debt issues with variables scaled by sales instead of book assets; the results were virtually identical. We also ran tests using deficits cumulated over a varying number of years and cumulative debt issues and cumulative changes in debt ratios. We corrected for first-order serial correlation and included firm-specific dummies. None of these variations were inconsistent with the results already described. However, an attempt to estimate firm-specific target adjustment coefficients yielded extremely poor fits.

contrary to the results in Table 2, we should have found positive constants and low explanatory power. 
We ran three other statistical specifications using the change in the debt ratio as the dependent variable. We estimated a variance components model with two way random effects as in Fuller and Batesse (1974), included a time dummy, following Dasilva (1975), and estimated a first-order autoregressive model with contemporaneous correlation as in Parks (1967). The results are given in Panel B of Table 2. The target adjustment coefficient and $R^{2}$ are reduced. The pecking order coefficient and $R^{2}$ also fall, but to a lesser extent. Standard errors increase, but coefficients remain highly significant. The overall story is unchanged. ${ }^{14}$

That story is as follows. First, a simple target adjustment model provides some explanatory power for changes in debt ratios, and its coefficients look reasonable and are statistically significant. However, a simple pecking order model has much better explanatory power.

\section{Anticipated vs. actual deficits}

We should consider whether the pecking order's high $\mathrm{R}^{2}$ s have more to do with shortterm adjustments than planned financing. Note that the pecking order regressions relate debt issues or retirements to contemporaneous deficits, including cash inflows or outflows which may be mid- or late-year surprises. Suppose we break out the surprises:

$$
D E F_{t}=E_{t}-1\left[D E F_{t}\right]+Z_{t}
$$

where $E_{t}-1\left[D E F_{t}\right]$ is the expected deficit at the end of year $t-1$ and $Z_{t}$ is the net unexpected funds inflow or outflow. $Z_{t}$ might be a good predictor of debt changes if it is difficult to issue or retire equity on short notice. This is not necessarily inconsistent with the pecking order -- information asymmetries provide one good reason why equity is not issued on short notice - but that theory is more convincing if companies also plan to cover deficits by issuing debt.

We cannot observe $E_{t}-1[D E F t]$ and so have to find an instrument. We use two: (1) the lagged deficit $D E F_{t}-1$, and (2) a "predicted" deficit using lagged values for funds from operations and changes in net working capital, but otherwise contemporaneous flows. Use of instrument (2) assumes that the other components of $\mathrm{DEF}_{\mathrm{t}}$, such as capital expenditures and dividends, are planned by management at the end of year $t-1$, and that year $t$ 's

14 We also ran a fixed effects model with very similar results. 
surprises are confined to funds from operations and changes in working capital. Use of instrument (1) hopes that there is enough serial correlation in individual firms' deficits that the lagged deficit is not too bad a predictor of the deficits forecasted by managers.

The top panel of Table 3 shows OLS pecking order results for gross debt issues using these two instruments. Coefficients and explanatory power naturally drop somewhat when the instruments are used alone, since they measure the true anticipated deficits with error. When the implied change in deficit or in operating funds is added to the regressions, the explanatory power improves as expected. However the significance of the instruments for the planned deficit are scarcely changed, indicating that the high explanatory power of our simple pecking order model is not driven merely by short-term adjustments to unanticipated financing deficits or surpluses.

The bottom panel of Table 3 nests the target adjustment and pecking order using the two instruments for the anticipated deficit. Once again, although the target adjustment coefficient is significant, its magnitude is considerably lower than the pecking order variable.

No doubt better models for the anticipated deficit could be constructed. However, Table 3 demonstrates that the high explanatory power of the pecking order is not driven by impediments to equity issues or retirements on short notice.

\section{Power}

The tests reported so far show that when the target adjustment and pecking order models are independently tested against a zero null, they both appear to describe the variation in debt ratios, although the pecking order wins the horse race when judged on raw explanatory power. In this section, we investigate the power of these tests. We demonstrate that the target adjustment model is frequently accepted even when it is known to be false. The simple pecking order test does not suffer from this lack of power; it is correctly rejocted when it is false.

We also demonstrate that several other tests of the static trade-off hypothesis likewise lack power. The apparently good performance of these tests is probably spurious. On the 
other hand, the results reported in this section reinforce our confidence in the pecking order as a description of financing behavior.

Why does the target adjustment model appear to explain financing decisions when underlying behavior is pure pecking order? There is a simple answer: our sample companies' capital expenditures are "lumpy" and their operating earnings cyclical. Since dividends are "sticky" and not used as a short-run offset to net funds requirements, the companies tend to have strings of years with financial deficits, followed by strings of surpluses (or vice versa). Under the pecking order the debt ratio climbs in deficit years and falls in surplus years. When the average debt ratio, measured ex post, is taken as the target, the pecking order debt ratios show (what appears as) mean-reversion. Thus the target adjustment models generate a misleadingly good fit.

Shyam-Sunder (1988) confirmed this by extensive simulations of hypothetical firms' financing policies. The pecking order was assumed to work exactly. Nevertheless, target adjustment models appeared to work when dividends adjusted slowly, when capital expenditures came in two- or three-year "lumps," and/or when operating income was cyclical or mean-reverting.

\section{Preview of the experiments}

Our experimental design is as follows. We take all elements of each firm's funds flow, except external financing, as exogenously determined. Using each firm's initial debt ratio in 1971 as a seed value, we generate a series of book debt ratios under alternative financing regimes. For example, a pecking order regime forces the firm to issue only debt when there is a financial deficit; a time series of debt ratios is computed under this assumption. Another series of debt ratios is generated assuming the firm follows a target adjustment rule with specified adjustment coefficients. Other hypothetical series are also generated, for example a random walk of debt ratios.

The tests summarized in Table 2 are then run independently on each of these series of debt ratios. If the tests have power, we should accept the pecking order model only for the series that were generated by a pecking order and reject it in all other cases. Likewise, we should reject the target adjustment model when it is fitted to series generated by the pecking order or a random walk.

Table 4 previews our tests and results. The first column refers to the sample firms' actual debt ratios. The remaining four columns refer to simulated debt ratios, based on 
actual firm data for the relevant exogenous variables. The rows refer to the fitted models. Naturally the models work perfectly when fitted to debt ratios generated by the same model. These cases are labelled "obvious accept."

If the pecking order test has power to reject, then, reading horizontally across Row 1 , we should find acceptance only in Column 2 and rejection in Columns 3, 4 and 5. Likewise, the basic target adjustment model (Row 2) should be accepted in Column 3 but rejected in Columns 2,4 and 5.

The pecking order is correctly rejected in all cases when an alternative financing rule is imposed. The target adjustment model is biased toward acceptance even when firms follow other financing rules. This result is robust to alternative specifications for the target adjustment rule including allowances for a moving target.

\section{Generating the financing time series}

Pecking order. We started with 1971 year-end values for each firm's book debt ratio. Later years' book debt ratios were then generated by determining the funds flow deficit, using actual data for operating cash flow, ${ }^{15}$ real investment, dividends, etc. The firm is assumed to issue debt if the deficit is positive and retire debt if it is negative. ${ }^{16}$ The predicted debt ratio for the end of the year is computed. The debt ratio for the next period is generated in the same way, except that a proportion of the simulated debt level of the previous year has to be repaid. This process is continued to generate a series of book debt ratios for each firm from 1971 to 1989 . This series tells us what the path of book debt ratios would be for each firm if, starting in 1971 , it had followed a strict pecking order.

Target adjustment model with fixed targets. This series again starts with the 1971 year end value of the book debt ratio. Ratios for later years are simulated according to the basic target adjustment equation. Each firm's target is proxied for by the actual historical mean book debt ratio from 1971 to 1989. This corresponds to specifications used in Taggart, Jalilvand and Harris, and Marsh. We report results for the hypothetical series generated using an adjustment coefficient of .4 (the empirical estimates of the

15We used actual operating cash flows, after interest and taxes, as in Eq. (1). We did not recalculate interest and taxes under the hypothetical financing policies. Thus our assumed pre-tax, pre-interest operating cash flows are not quite true to real life. This does not affect the tests of statistical power reported in Table 5.

${ }^{16}$ We also developed time series of debt ratios assuming that funds surpluses were not used to pay down debt but instead held as cash. The results were basically unchanged. 
adjustment coefficient in Table 2 are .33 and .41) and a error-term variance of .10 . This series tells us what the book debt ratio path would be for each firm if, starting in 1971, it had followed a target adjustment rule with these parameters.

Of course the static trade-off theory doesn't require any particular numerical value for the adjustment coefficient. Therefore we varied the adjustment coefficient from 11 to 1.0 (but constrained it to be the same for each firm) and the variance of the error term from 0 and .2. Our results are robust over these ranges except at very low values of the adjustment coefficient.

Target adjustment models with moving targets. Static trade-off models maintain that a firm's optimal debt ratio is a function of risk, asset type, tax status and profitability. Obviously these factors change. We used some proxies for the factors to specify several pooled time-series cross-section models with moving target debt ratios. One example is:

$$
\Delta d_{i t}=a+b_{1} \text { (Plant) }+b_{2}(R \& D)+b_{3}(\text { Tax })+b_{4} \text { (Eamings), }
$$

where Plant is the ratio of plant and equipment to sales or assets, a proxy for fixed assets; $R \& D$ is the ratio of research and development expenditures to sales or assets, a proxy either for intangible assets or growth opportunities; Tax is the ratio of taxes paid to sales or assets, a proxy for the tax-paying status of the firm, and Eamings is the ratio of operating earnings to sales or assets, a proxy for profitability.

One can easily think of other proxies. The static trade-off theory does not specify them. and the literature has employed a wide range of variables. We have checked a variety of alternative specifications and the above equation is reported only as an example. The $R^{2}$ of most alternative specifications were similar. This is discussed further below.

The simulated debt ratio series are generated by using the 1971 value of the book debt ratio of each firm as the seed value and then generating the subsequent values by the following equation:

$$
\Delta \mathrm{d}_{\mathrm{it}}=.3 \Delta(\mathrm{Plant})-.2 \Delta(\mathrm{R} \& \mathrm{D})+.2 \Delta(\mathrm{Tax})+.3 \Delta \text { (Earnings) }
$$

Random walk. This series is generated as a final alternative. The seed value as before is the 1971 book debt ratio for each firm and a random series of book debt ratios is 
generated with reflecting barriers at 0 and 1.0 and variances ranging from 0 to $.2^{17}$. The results reported are for a variance of 10 .

\section{The fitted models}

Panel A of Table 5 shows the results of fitting the pecking order model to the various series. With the exception of the extremely good fit to actual data, the model fares extremely poorly. We infer that the fit we observe on real data is not spurious.

Panel B shows the results of fitting the target adjustment model to the various series. As reported earlier, the model fits actual data. It fits the pecking order series equally well! While the results are somewhat weaker for the other series, we still fail to reject the simple target adjustment model, even when the series of debt ratios is a random walk!

\section{Cross sectional tests}

The results so far strongly increase our confidence in the pecking order against the target adjustment model. However, our specification of the static trade-off theory is only one of several possible treatments and interpretations. The literature also contains a large number of studies of relationships between leverage and proxies for determining factors. As Harris and Raviv (1991) point out, "These studies generally agree that leverage increases with fixed assets, nondebt tax shields, growth opportunities, and firm size and decreases with volatility, advertising expenditures, research and development expenditures, bankruptcy probability, profitability and uniqueness of product."18 Examples of such tests include Bradley et al (1984), Kester (1986), Long and Malitz (1985), and Baskin (1985), who test the trade-off theory using cross-sectional regressions of debt ratios against various proxy variables. Do such tests have power? We can check by fitting representative cross sectional models to the actual data and the simulated series.

These models are estimated in two ways. In one specification, firmwise averages of the relevant variables for the entire period are used in the regressions. In the other, a cross sectional regression equation is estimated for each year from 1971 to 1989.

The cross sectional models' performance is mixed. For example, the significance of the independent variables varies year to year in the cross sectional regressions. However, there are almost always significant coefficients that could be read as supporting the static trade-

17 Reflecting barriers of .8 and .2 and .9 and .1 were also tested with similar results. ${ }^{18}$ p. 334 
off theory. The theory cannot be definitely rejected on either actual or simulated debt ratios. This result emerges when the regressions are run year to year and also when using period averages.

Tables $6 \mathrm{a}$ and $6 \mathrm{~b}$ report typical results, in this case for the regression using sample period averages. Note that debt ratios appear to be significantly positively related to the proportion of fixed plant and equipment and negatively related to profitability. The coefficients on other proxies in this particular specification are weak. However, the rejection of the zero null would not necessarily support the trade-off theory even if it were stronger, since the fit of the model is not appreciably different when applied to the series generated by the pecking order or the simple fixed target adjustment model. The only series for which this test would correctly reject is the random walk.

The essential point is this: a firm could be following a pure pecking order, not driven at all by conventional trade-off considerations, yet cross-sectional tests using reasonable proxies would suggest at least partial acceptance of the trade-off theory of capital structure. This underscores our central theme that tests of the traditional theories on capital structure against a zero null are not persuasive evidence.

\section{Auerbach's model}

The final experiment addresses Auerbach's (1984) formulation of the traditional theory. He analyzes a panel of data and allows for firm specific as well as time-varying targets. ${ }^{19}$ The basic methodology is as follows.

The pure target adjustment model implies a long-run target debt ratio based on firm characteristics and a lag in adjustment to changes in this desired ratio. The target ratio $\mathrm{d}_{\mathrm{it}}^{*}$ is assumed to be a linear function of determining variables which vary over time and over firms. The model to be estimated is

$$
\Delta d_{i t}=b\left(d_{i t}^{*}-d_{i t-1}\right)
$$

where $d_{i t}^{*}=A X_{i t}$, is the target debt ratio for firm $i$ at time $t$.

The vector $\mathrm{X}_{\mathrm{it}}$ includes dummy variables for each firm and each year (except the first); $A$ is a vector of coefficients. Because most of the other explanatory variables change only

${ }^{19}$ Auerbach also carefully constructs real measures of all variables and conducts a series of alternative tests differentiating, among other things, between short and longterm debt targets. We consider only one of his many specifications. 
slowly, only the firm's tax loss carry forwards in the previous year are included in the initial estimation. The other explanatory variables are used in a second stage estimation to explain the variation in individual firm constants in a cross-section regression. This procedure allows for large unexplained firm specific effects.

Representative results for this procedure using actual book debt ratios are shown in the first column of Table 7. The adjustment coefficient is .28 (corresponding to the negative of the coefficient on lagged debt), which is significant and almost the same as Auerbach's .27. The $\mathrm{R}^{\mathbf{2}}$ of .20 is also similar to Auerbach's, but while our coefficient on lagged tax loss carry forwards has the right sign, it is not significant.

In the second stage, the firm's target debt ratio is related to explanatory variables. The dependent variable in this stage is the coefficient of the firm's dummy from the first stage. Our choice of explanatory variables is guided by Auerbach, although some of the variables used in his estimation were unavailable. As in Auerbach, the asset composition variables shown in Table 7 have the predicted sign and are statistically significant. The $R^{2}$ from this second stage are considerably lower than in Auerbach, however.

Columns 2 and 3 show the results of replicating these tests on the debt ratios generated by a pecking order and a random walk respectively. Once again the hypothesis of target adjustment is strongly supported even though the explanation of the firm-specific coefficients in the second stage is poorer than with real data. However, Auerbach also places only limited value on the role of explanatory variables 20 and stresses the adjustment coefficients as support for target adjustment models of corporate borrowing. Our results suggest that significance of the adjustment coefficients are likewise inconclusive.

\section{Conclusions}

This study reexamines some aspects of the empirical literature on capital structure. Others, such as Titman and Wessels (1988), have also attempted to test various models by including all hypotheses jointly in the empirical tests. Instead, we view the theories as contending hypotheses and examine their relative explanatory power. The attention to power is an important methodological point.

\footnotetext{
20 At p. 318 he concludes that "... some firm characteristics are insignificant in explaining cross-sectlonal differences in leverage, while others appear to contradict the predictions of various theories... . ... richer models of firm behavior appear to be required before more definitive conclusions can be reached."
} 
Our main conclusions can be summarized as follows. (1) The pecking order is an effective first-order descriptor of corporate financing behavior. (2) The simple target adjustment model, when tested independently, also seems to be a good descriptor. (3) When the two models are nested, the coefficient and significance of the pecking order variable change hardly at all; the performance of the target adjustment model's variable degrades. (4) The strong performance of the pecking order does not occur just because firms fund unanticipated cash needs with debt in the short run. Our results indicate that firms plan to finance anticipated deficits with debt. (5) Our experiments show that the simple target adjustment models are not rejected even when false; the pecking onder, when false, can be easily rejected.

Overall, the results suggest greater confidence in the pecking order than in the target adjustment model. If companies do have a well-defined optimal capital structure, it seems that managers are not much interested in getting there.

Several caveats are in order. First, our models are simple. Our experiments have considered only a few specifications of the trade-off theory of optimal capital structure. Richer specifications have been, or could be, tested, for example some of the variations in JalilvandHarris and in Fischer, Heinkel and Zechner (1989), which allow for adjustment coefficients to vary by firm and relate them to the costs and benefits of deviation from targets. Fischer, Heinkel and Zechner also develop a dynamic inventory adjustment model of capital structure that could be more realistic than ordinary target adjustment models.

Nevertheless, this paper shows that sharper models are called for. In particular, empirical work on capital structures must devise tests of hypotheses that can be rejected. This is a challenge to both theoretical and empirical research. 
Table 1

Descriptive statistics for the sample of 157 firms for 1971, 1981 and 1989. Data are taken from the Industrial Compustat tapes. Dollar figures in millions.

$1971 \quad 1981$

Book value of assets

$\begin{array}{llll}\text { Mean } & \$ 220 & 605 & 2034 \\ \text { Median } & 79 & 176 & 135 \\ \text { Maximum } & 10509 & 23021 & 160893 \\ \text { Minimum } & 3 & 4 & 4\end{array}$

Market value of equity

$\begin{array}{llll}\text { Mean } & \$ 185 & 248 & 890 \\ \text { Median } & 136 & 143 & 790 \\ \text { Maximum } & 7265 & 3359 & 20625 \\ \text { Minimum } & 2 & 3 & 2\end{array}$

Book debt ratio

$\begin{array}{llll}\text { Mean } & .18 & .18 & .19 \\ \text { Median } & .17 & .13 & .17 \\ \text { Maximum } & .82 & .68 & .79 \\ \text { Minimum } & 0 & 0 & 0\end{array}$

Return on assets

$\begin{array}{llll}\text { Mean } & .147 & .154 & .115 \\ \text { Median } & .136 & .149 & .123 \\ \text { Maximum } & .50 & .58 & .36 \\ \text { Minimum } & -.22 & -.6 & -.31\end{array}$

Number of firms with tax loss carry forwards $\quad 23 \quad 16 \quad 28$

Notes:

1. The book debt ratio is the ratio of long term debt to the book value of assets. The book value of assets includes net working capital.

2. Return on assets is the ratio of after-tax operating eamings to book value of assets. 


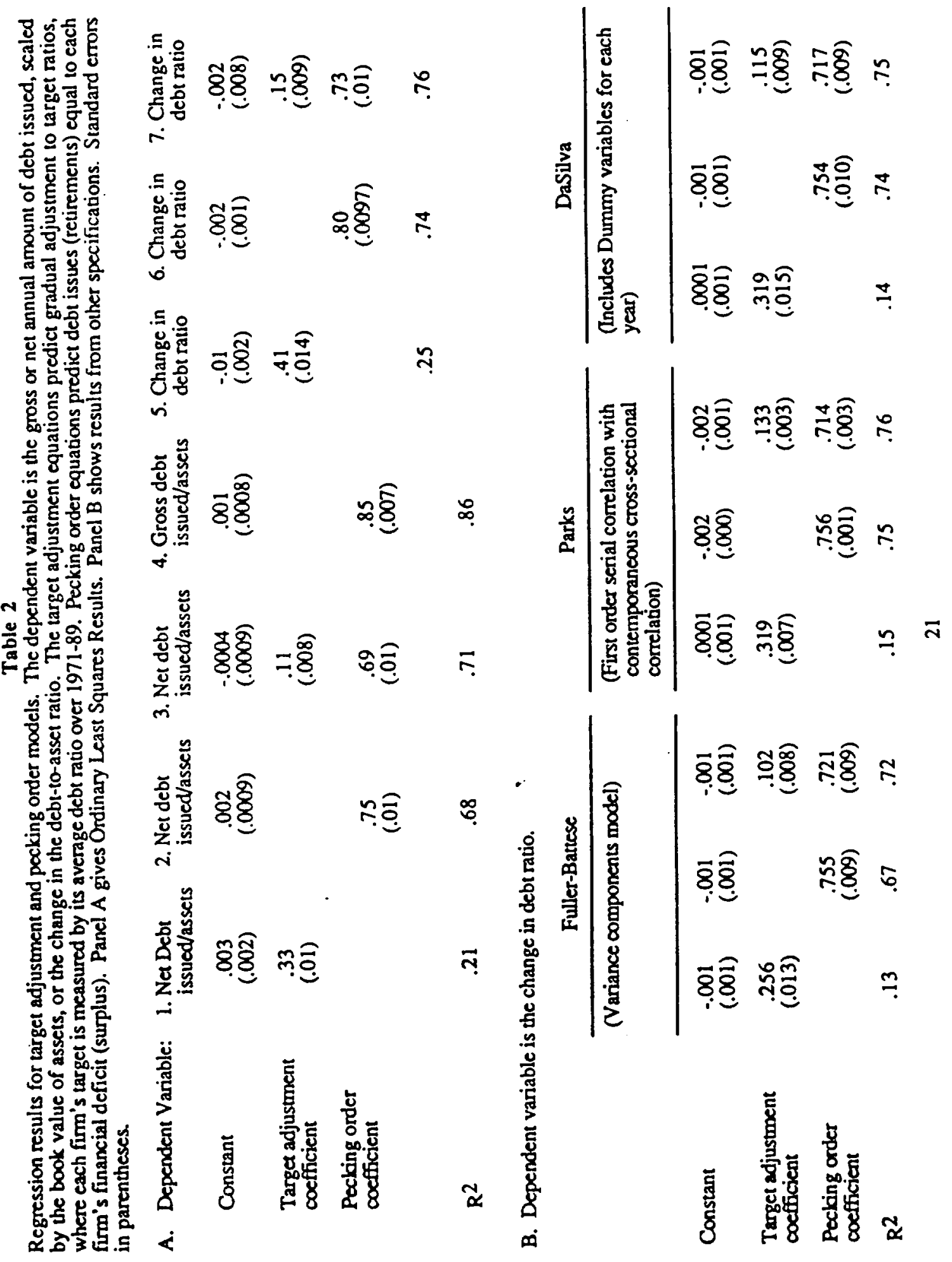


Table 3

Ondinary least squares regression results for pecking order using instruments for the anticipated deficit. Standard errors in parentheses. All variables scaled by book assets.

Dependent variable: Gross debt issued

Constant

.001

$(.001)$

.002

$(.0009)$

.007

$(.0007)$

.007

$(.0008)$

Lagged deficit 1

Change in deficit

.17

(.01)

Deficit with lagged funds

.78

(.01)

from operations ${ }^{2}$

Change in funds from operations

R2

.64

.81

.78

.80

Dependent variable: Net debt issued

Constant

.0001

$(.0004)$

.0001

$(.0007)$

.0008

.19

(.01)

.13

(.01)

.11

(.01)

.11

(.01)
.54

(.01)

.16

(.01)

Deficit with lagged funds

from operations ${ }^{2}$

Change in funds from operations

$\mathbf{R}^{2}$

Notes:

1. Previous year's actual deficit $D E F_{t-1}$. The change in the deficit is $D E F_{t}-D E F_{t-1}$.

2 Contemporaneous deficit, except that funds from operations and net working capital are lagged one period. The change in funds from operations is the change in these two components. 
Table 4

Summary of tests of power of target adjustment and pecking order regressions. "Accept" means plausible and statistically significant coefficients, "reject" the opposite. Detailed results for actual data are in Table 2; for simulated data in Tables 5 - 8. "Simulated data" refers to the simulated financing policies for 157 actual firms from 1971-89.

\begin{tabular}{|c|c|c|c|c|c|}
\hline \multirow[b]{2}{*}{$\begin{array}{c}\text { Model } \\
\text { Estlmated }\end{array}$} & \multirow[b]{2}{*}{$\begin{array}{c}\text { Results for } \\
\text { Actual } \\
\text { Financing }\end{array}$} & \multicolumn{4}{|c|}{ Results for Simulated Financing } \\
\hline & & $\begin{array}{l}\text { Pecking } \\
\text { Order }\end{array}$ & $\begin{array}{c}\text { Target } \\
\text { Adjustment } \\
\text { (Fixed } \\
\text { Target) }\end{array}$ & $\begin{array}{c}\text { Target } \\
\text { Adjustment } \\
\text { (Moving } \\
\text { Target) }\end{array}$ & $\underset{\text { Walk }}{\text { Random }}$ \\
\hline Pecking Order & Accept & $\begin{array}{l}\text { Obvious } \\
\text { Accept }\end{array}$ & Reject & Reject & Reject \\
\hline $\begin{array}{l}\text { Target } \\
\text { Adjustment } \\
\text { (Fixed Target) }\end{array}$ & Accept & Accept & $\begin{array}{l}\text { Obvious } \\
\text { Accopt }\end{array}$ & Accept & Accept \\
\hline $\begin{array}{l}\text { Target } \\
\text { Adjustment } \\
\text { (Moving Target) }\end{array}$ & $\begin{array}{l}\text { Partlal } \\
\text { Accopt }\end{array}$ & $\begin{array}{l}\text { Partial } \\
\text { Accept }\end{array}$ & $\begin{array}{l}\text { Partial } \\
\text { Accept }\end{array}$ & $\begin{array}{l}\text { Obvious } \\
\text { Accept }\end{array}$ & $\begin{array}{l}\text { Partial } \\
\text { Accept }\end{array}$ \\
\hline $\begin{array}{l}\text { Cross-sectional } \\
\text { Static Order }\end{array}$ & $\begin{array}{l}\text { Partial } \\
\text { Accept }\end{array}$ & $\begin{array}{l}\text { Partial } \\
\text { Accopt }\end{array}$ & $\begin{array}{l}\text { Partial } \\
\text { Accept }\end{array}$ & $\begin{array}{l}\text { Partial } \\
\text { Accept }\end{array}$ & Reject \\
\hline
\end{tabular}




\section{Table 5}

Results of fitting the pecking order and target adjustment models to (1) actual debt ratios, and to simulated debt ratios assuming (2) target adjustment with a fixed target -- or financing by the pecking order in Panel B, (3) target adjustment with a moving target and (4) a random walk of debt ratios. Simulated and actual data are for 157 firms from 1971 to 1989. The dependent variable is the change in the book debt to assets ratio. Panel A shows results for the pecking order model; Panel B for the target adjustment (mean-reverting) model. Standard errors of coefficients in parentheses.

\begin{tabular}{|c|c|c|c|c|}
\hline $\begin{array}{l}\text { A. Pecking } \\
\text { Order } \\
\text { Model }\end{array}$ & $\begin{array}{c}1 \\
\text { Actual } \\
\text { Data }\end{array}$ & $\begin{array}{c}2 \\
\text { Target Adjustment } \\
\text { (Fixed Target) }\end{array}$ & $\begin{array}{c}3 \\
\text { Target Adjustment } \\
\text { (Moving Target) }\end{array}$ & $\begin{array}{c}4 \\
\text { Random } \\
\text { Walk }\end{array}$ \\
\hline Constant & $\begin{array}{l}-0.01 \\
(0.01)\end{array}$ & $\begin{array}{c}0.00 \\
(0.00)\end{array}$ & $\begin{array}{c}0.00 \\
(0.00)\end{array}$ & $\begin{array}{c}0.00 \\
(0.00)\end{array}$ \\
\hline $\begin{array}{l}\text { Pocking Order } \\
\text { coefficient }\end{array}$ & $\begin{array}{c}0.84 \\
(0.01)\end{array}$ & $\begin{array}{c}0.02 \\
(0.01)\end{array}$ & $\begin{array}{l}-0.13 \\
(0.01)\end{array}$ & $\begin{array}{l}-0.04 \\
(0.02)\end{array}$ \\
\hline $\mathbf{R}^{2}$ & 0.75 & 0.02 & 0.05 & 0.01 \\
\hline $\begin{array}{l}\text { B. Target } \\
\text { Adjustment } \\
\text { Model }\end{array}$ & $\begin{array}{c}1 \\
\text { Actual } \\
\text { Data }\end{array}$ & $\begin{array}{l}2 \\
\text { Pecking } \\
\text { Order }\end{array}$ & $\begin{array}{l}3 \\
\text { Target Adjustment } \\
\text { (Moving Target) }\end{array}$ & $\begin{array}{c}4 \\
\text { Random } \\
\text { Walk }\end{array}$ \\
\hline Constant & $\begin{array}{l}-0.01 \\
(0.07)\end{array}$ & $\begin{array}{l}-0.05 \\
(0.01)\end{array}$ & $\begin{array}{c}0.01 \\
(0.01)\end{array}$ & $\begin{array}{c}0.00 \\
(0.00)\end{array}$ \\
\hline \multirow{2}{*}{$\begin{array}{l}\text { Target } \\
\text { adjustment } \\
\text { coefficient } \\
\mathbf{R}^{2}\end{array}$} & $\begin{array}{c}0.30 \\
(0.02)\end{array}$ & $\begin{array}{c}0.23 \\
(0.01)\end{array}$ & $\begin{array}{c}0.42 \\
(0.20)\end{array}$ & $\begin{array}{c}0.16 \\
(0.01)\end{array}$ \\
\hline & 0.15 & 0.12 & 0.20 & 0.07 \\
\hline
\end{tabular}


Table 6a

Results of estimating a cross-soctional static static trade-off model on (1) actual debt ratios, and simulated debt ratios generated by (2) pecking order financing, (3) target adjustment with a fixed target and (4) a random walk. Simulated and actual data are for 157 firms from 1971 to 1989. The dependent variable is the average debt ratio for each firm. Independent variables are also averaged for each firm over 1971 to 1989 . $t$-statistics in parentheses.

\begin{tabular}{|c|c|c|c|c|}
\hline & 1 & 2 & 3 & 4 \\
\hline & $\begin{array}{c}\text { Actual } \\
\text { Data }\end{array}$ & $\begin{array}{l}\text { Pecking } \\
\text { Order }\end{array}$ & $\begin{array}{l}\text { Target Adjustment } \\
\text { (Fixed Target) }\end{array}$ & $\begin{array}{l}\text { Random } \\
\text { Walk }\end{array}$ \\
\hline \multicolumn{5}{|l|}{ BANELA } \\
\hline Constant & $\begin{array}{c}0.21 \\
(12.08)\end{array}$ & $\begin{array}{r}0.21 \\
(11.36)\end{array}$ & $\begin{array}{c}0.19 \\
(11.89)\end{array}$ & $\begin{array}{l}0.20 \\
(8.04)\end{array}$ \\
\hline $\begin{array}{l}\text { Tax Loss } \\
\text { Cancy Forwand/Sales }\end{array}$ & 0.38 & 0.06 & $\begin{array}{l}0.01 \\
(0.13)\end{array}$ & 0.11 \\
\hline R\&D/Sales & $\begin{array}{l}-0.43 \\
(-0.94)\end{array}$ & $\begin{array}{c}0.33 \\
(0.64)\end{array}$ & $\begin{array}{c}-0.37 \\
(-0.82)\end{array}$ & $\begin{array}{c}-0.12 \\
(-0.23)\end{array}$ \\
\hline Plan/Sales & $\begin{array}{c}0.15 \\
(4.88)\end{array}$ & $\begin{array}{l}0.18 \\
(5.31)\end{array}$ & $\begin{array}{l}0.15 \\
(4.90)\end{array}$ & $\begin{array}{l}0.08 \\
(1.79)\end{array}$ \\
\hline Eamings/Sales & $\begin{array}{l}-0.64 \\
(-3.94)\end{array}$ & $\begin{array}{c}-0.79 \\
(-4.19)\end{array}$ & $\begin{array}{c}-0.62 \\
(-3.81)\end{array}$ & $\begin{array}{l}-0.23 \\
(0.94)\end{array}$ \\
\hline $\mathrm{R}^{2}$ & 0.22 & 0.24 & 0.19 & 0.04 \\
\hline \multicolumn{5}{|l|}{ PANEL B } \\
\hline Constant & $\begin{array}{l}0.15 \\
(5.15)\end{array}$ & $\begin{array}{c}0.14 \\
(4.11)\end{array}$ & $\begin{array}{c}0.15 \\
(5.25)\end{array}$ & $\begin{array}{l}0.19 \\
(3.78)\end{array}$ \\
\hline \multicolumn{5}{|l|}{ Tax Loss } \\
\hline Carry Forward/Assets & $\begin{array}{c}0.02 \\
(0.12)\end{array}$ & $\begin{array}{c}0.09 \\
(0.59)\end{array}$ & $\begin{array}{c}-0.03 \\
(-0.21)\end{array}$ & $\begin{array}{c}-0.10 \\
(-0.47)\end{array}$ \\
\hline R\&D/Assets & $\begin{array}{l}-0.63 \\
-1.80\end{array}$ & $\begin{array}{l}-0.10 \\
-(0.25)\end{array}$ & $\begin{array}{l}-0.59 \\
(-1.65)\end{array}$ & $\begin{array}{l}0.08 \\
(0.14)\end{array}$ \\
\hline Plant/Assets & $\begin{array}{c}0.29 \\
(7.79)\end{array}$ & $\begin{array}{l}0.35 \\
(7.90)\end{array}$ & $\begin{array}{l}0.29 \\
(7.61)\end{array}$ & $\begin{array}{l}0.24 \\
(3.91)\end{array}$ \\
\hline Earnings/Assets & $\begin{array}{c}-0.71 \\
(-4.74)\end{array}$ & $\begin{array}{c}-0.75 \\
(-423)\end{array}$ & $\begin{array}{c}-0.73 \\
(-4.78)\end{array}$ & $\begin{array}{c}-0.60 \\
(-2.41)\end{array}$ \\
\hline$R^{2}$ & 0.38 & 0.37 & 0.35 & 0.09 \\
\hline
\end{tabular}




\section{Table 6b}

Results of estimating a cross-sectional static static trade-off model on (1) actual debt ratios, and simulated debt ratios generated by (2) pecking order financing, (3) target adjustment with a fixed target and (4) a random walk. Simulated and actual data are for 157 firms from 1971 to 1989. The dependent variable is the average debt ratio for each firm. Independent variables are also averaged for each firm over 1971 to $1989 . t$-statistics in parentheses.

\begin{tabular}{|c|c|c|c|c|c|c|}
\hline PANELA & \multicolumn{2}{|c|}{$\underset{\substack{1 \\
\text { Datala }}}{ }$} & \multicolumn{2}{|c|}{$\begin{array}{c}2 \\
\text { Pecking } \\
\text { Order }\end{array}$} & \multicolumn{2}{|c|}{$\begin{array}{c}3 \\
\text { Random } \\
\text { Walk }\end{array}$} \\
\hline Constant & $\begin{array}{r}0.15 \\
(11.59)\end{array}$ & $\begin{array}{c}0.19 \\
(13.64)\end{array}$ & $\begin{array}{c}0.16 \\
(10.64)\end{array}$ & $\begin{array}{c}0.21 \\
(13.6)\end{array}$ & $\begin{array}{l}0.18 \\
(9.51)\end{array}$ & $\begin{array}{c}0.21 \\
(10.04)\end{array}$ \\
\hline $\begin{array}{l}\text { Tax Loss Carry } \\
\text { Fonward/Sales }\end{array}$ & $\begin{array}{c}0.14 \\
(2.11)\end{array}$ & $\begin{array}{c}0.03 \\
(0.41)\end{array}$ & $\begin{array}{c}0.21 \\
(2.61)\end{array}$ & $\begin{array}{c}0.05 \\
(0.60)\end{array}$ & $\begin{array}{c}0.14 \\
(1.41)\end{array}$ & $\begin{array}{c}0.04 \\
(0.35)\end{array}$ \\
\hline R\&D/Sales & $\begin{array}{r}-0.55 \\
(-1.47)\end{array}$ & $\begin{array}{r}-0.67 \\
(-1.94)\end{array}$ & $\begin{array}{r}0.02 \\
(0.06)\end{array}$ & $\begin{array}{c}-0.13 \\
(-0.35)\end{array}$ & $\begin{array}{c}-0.21 \\
(-0.40)\end{array}$ & $\begin{array}{c}-0.32 \\
(-0.61)\end{array}$ \\
\hline Capex/Sales & $\begin{array}{c}0.23 \\
(3.07)\end{array}$ & $\begin{array}{c}0.75 \\
(6.29)\end{array}$ & $\begin{array}{r}0.32 \\
(3.65)\end{array}$ & $\begin{array}{c}1.02 \\
(7.59)\end{array}$ & $\begin{array}{c}0.28 \\
(2.57)\end{array}$ & $\begin{array}{c}0.74 \\
(4.07)\end{array}$ \\
\hline Eamings Variance & $\begin{array}{c}0.00 \\
(0.35)\end{array}$ & $\begin{array}{c}0.01 \\
(0.35)\end{array}$ & $\begin{array}{c}0.11 \\
(-0.09)\end{array}$ & $\begin{array}{r}0.00 \\
(-0.14)\end{array}$ & $\begin{array}{c}-0.01 \\
(-0.14)\end{array}$ & $\begin{array}{c}-0.01 \\
(-0.16)\end{array}$ \\
\hline OpFunde/Sales & & $\begin{array}{l}(-0.82) \\
(-5.35)\end{array}$ & & $\begin{array}{l}-1.10 \\
(-6.38)\end{array}$ & & $\begin{array}{c}-0.73 \\
(-3.11)\end{array}$ \\
\hline $\mathbf{R}^{2}$ & 0.12 & $(0.26)$ & 0.15 & 0.33 & 0.06 & 0.11 \\
\hline \multicolumn{7}{|l|}{ PANEI $B$} \\
\hline Constant & $\begin{array}{l}0.09 \\
(4.24)\end{array}$ & $\begin{array}{c}0.25 \\
(9.60)\end{array}$ & $\begin{array}{c}0.07 \\
(3.06)\end{array}$ & $\begin{array}{c}0.27 \\
(9.13)\end{array}$ & $\begin{array}{c}0.13 \\
(3.94)\end{array}$ & $\begin{array}{l}0.23 \\
(5.01)\end{array}$ \\
\hline $\begin{array}{l}\text { Tax Loss Carny } \\
\text { Fonward }\end{array}$ & $\begin{array}{l}0.41 \\
(3.19)\end{array}$ & $\begin{array}{c}-0.17 \\
(-1.32)\end{array}$ & $\begin{array}{l}0.54 \\
(3.57)\end{array}$ & $\begin{array}{c}-0.16 \\
(-1.13)\end{array}$ & $\begin{array}{c}0.23 \\
(1.15)\end{array}$ & $\begin{array}{l}-0.16 \\
(-0.70)\end{array}$ \\
\hline$R \& D / A s s e t s$ & $\begin{array}{r}-0.99 \\
(-258)\end{array}$ & $\begin{array}{r}-0.87 \\
(-2.87)\end{array}$ & $\begin{array}{r}-0.49 \\
(-1.08)\end{array}$ & $\begin{array}{c}-0.33 \\
(-0.91)\end{array}$ & $\begin{array}{c}-0.18 \\
(-0.29)\end{array}$ & $\begin{array}{c}-0.09 \\
(-0.15)\end{array}$ \\
\hline Capex/Assets & $\begin{array}{c}1.13 \\
(5.54)\end{array}$ & $\begin{array}{l}1.90 \\
(9.95)\end{array}$ & $\begin{array}{c}1.51 \\
(6.31)\end{array}$ & $\begin{array}{r}2.44 \\
(11.12)\end{array}$ & $\begin{array}{r}0.99 \\
(3.17)\end{array}$ & $\begin{array}{c}1.52 \\
(4.36)\end{array}$ \\
\hline Eamings Variance & $\begin{array}{c}0.01 \\
(0.76)\end{array}$ & $\begin{array}{c}0.00 \\
(0.75)\end{array}$ & $\begin{array}{c}0.00 \\
(0.21)\end{array}$ & $\begin{array}{c}0.00 \\
(0.09)\end{array}$ & $\begin{array}{c}0.00 \\
(0.04)\end{array}$ & $\begin{array}{c}-0.01 \\
(-0.01)\end{array}$ \\
\hline OpFunds/Assets & & $\begin{array}{c}-2.12 \\
(-8.37)\end{array}$ & & $\begin{array}{l}-2.58 \\
(-8.84)\end{array}$ & & $\begin{array}{c}-1.43 \\
(-3.10)\end{array}$ \\
\hline $\mathrm{R}^{2}$ & 0.23 & 0,48 & 0.25 & 0.51 & 0.04 & 0.1 \\
\hline
\end{tabular}




\section{Table 7}

Results of Estimating a Moving Target Adjustment Model on Actual debt ratios and debt ratios generated by (1) Pecking Order and (2) a Random Walk for 175 Firms over 1971 to 1989 (standard errors of coefficients in parentheses.)

$\begin{array}{ccc}1 & 2 & 3 \\ \text { Actual } & \text { Pecking } & \text { Random } \\ \text { Data } & \text { Order } & \text { Walk }\end{array}$

\section{Eirst Stage}

Dependent variables: $\Delta d_{i t}$

Indepeadent variabiex

Tax lose carry forward $\times 10^{-3}$ $-0.05$

$(0.04)$

Lagged debt

$-0.28$

0.01

0.00

$(0.04) \quad(0.00)$

$-0.17-0.18$

$(0.02)$

$(0.01)$

Second Stape

Dependent variable

(from coefficients

from Stage 1)

Independean variable

$\begin{array}{lcll}\text { Intercept } & 0.09 & -0.03 & 0.14 \\ & (0.03) & (0.05) & (0.05) \\ \text { R\&D/Assets } & -0.86 & -0.27 & 0.62 \\ & (0.39) & (0.60) & (0.65) \\ \text { Pland/Assets } & 0.07 & 0.11 & 0.01 \\ & (0.04) & (0.07) & (0.07) \\ \text { Earnings/Assets } & -0.11 & 0.01 & -0.45 \\ & (0.15) & (0.23) & (0.25) \\ \text { Variance (X10-3) } & -0.21 & -0.21 & 0.00 \\ & (0.01) & (0.01) & (0.01) \\ \bar{R}^{2} & & & \end{array}$




\section{REFERENCES}

This paper has benefited from comments by seminar participants at Boston College, Boston University, Dartmouth College, MIT, University of Massachusetts, Ohio State University, UCLA and the NBER, especially Eugene Fama and Robert Gertner. The usual disclaimers apply. Funding from MTT and The Tuck School at Dartmouth College is gratefully acknowledged.

Auerbach, A.S., 1985, Real determinants of corporate leverage, in: B. M. Friedman, ed., Corporate capital structures in the United States (National Bureau of Economic Research) 301-322.

Baskin, J., 1985, On the financial policy of large mature corporations, Unpublished Ph.D. dissertation (Harvard University, Cambridge, MA).

Bradley, M., Jarrel, G.A. and E. H. Kim, July 1984, On the existence of an optimal capital structure: Theory and evidence, Joumal of Finance 39, 857-78.

Da Silva, J.G.C., 1975, The analysis of cross-sectional time series data, Ph. D. dissertation (Department of Statistics, North Carolina State University).

Drtina, R. and J. Largay, 1985, Pitfalls in calculating cash flows from operations, Accounting Review, 314-326.

Eckbo, B.E., 1986, Valuation effects of corporate debt offerings, Journal of Financial Economics 15, 119-152.

Fazzari, S., Hubbard, G. and B.Petersen, 1988, Financing constraints and corporate investments (Brookings Papers on Economic Activity) 141-206.

Fischer, E., Heinkel, R. and J. Zechner, 1989, Dynamic capital structure choice: Theory and tests, Journal of Finance 44, 19-40.

Fuller, W.A. and G.E. Battese, 1974, Estimation of linear models with crossed-error structure, Journal of Econometrics 2, 67-78.

Harris, M. and A. Raviv, 1991, The theory of capital structure, Journal of Finance, 46, 297-355.

Hoshi, T., Kashyap, A. and D. Scharfstein, 1991, Corporate structure, liquidity, and investment: Evidence from Japanese industrial groups, Quarterly Journal of Economics 56, 33-60.

Jensen, M.C., 1986, Agency costs of free cash flow, corporate finance and takeovers, American Economic Review.

Jalilvand, A. and R. S. Harris, 1984, Corporate behavior in adjusting to capital structure and dividend targets: An econometric study, Joumal of Finance 39, 127-145.

Kester, C.W., 1986, Capital and ownership structure: A comparison of United States and Japanese manufacturing corporations, Financial Management 15, 97-113. 
Long, M.S. and E. B. Malitz, 1985, Investment patterns and financial leverage, in: B. Freidman, ed., Corporate capital structures in the United States (Chicago, University of Chicago Press).

Mackie-Mason, J., December 1990, Do taxes affect corporate financing decisions?, Journal of Finance 45, 1471-1494.

Masulis, R.W., 1980, The effects of capital structure change on security prices: A study of exchange offers, Joumal of Financial Economics 8, 139-177.

Marsh, P., March 1982, The choice between equity and debt: An empirical study, Joumal of Finance 37, 121-44.

Miller, M.H. and F. Modigliani, June 1966, Some estimates of the cost of capital to the electric utility industry, 1954-57, American Economic Review 57, 333-391.

Myers, S.C., 1977, Determinants of corporate borrowing, Journal of Financial Economics 5, 147-175.

Myers, S.C., July 1984, The capital structure puzzle, Journal of Finance 39, 575-92.

Myers, S.C. and N. Majluf, June 1984, Corporate financing and investment decisions when firms have information investors do not have, Journal Of Financial Economics 13, 187-221.

Parks, R.W., 1967, Efficient estimation of a system of regression equations when disturbances are both serially and contemporaneously correlated, Joumal of the American Statistical Association 62, 500-509.

Rajan, R.G. and L. Zingales, January 1994, What do we know about capital structure? Some evidence from intemational data (Graduate School of Business, University of Chicago).

Schwartz, E. and R. Aronson, March 1967, Some surrogate evidence in support of the concept of optimal financial structure, Joumal of Finance 22, 10-18.

Smith, C.W. and R. L. Watts, 1992, The investment opportunity set and corporate financing, dividend, and compensation policies, Journal of Financial Economics $32,263-292$.

Shyam-Sunder, L., 1991, The stock price effect of risky versus safe debt, Joumal of Financial and Quantitative Analysis 26, 549-558.

Taggart, R.A., 1977, A model of corporate financing decisions, Joumal of Finance 32 , 1467-1484.

Titman, S. and R. Wessels, March 1988, The determinants of capital structure choice, Joumal of Finance 43, 1-19.

Whited, T., 1992, Debt, liquidity constraints, and corporate investment: Evidence from panel data, Journal of Finance 47, 1425-1460. 
</ref_section> 


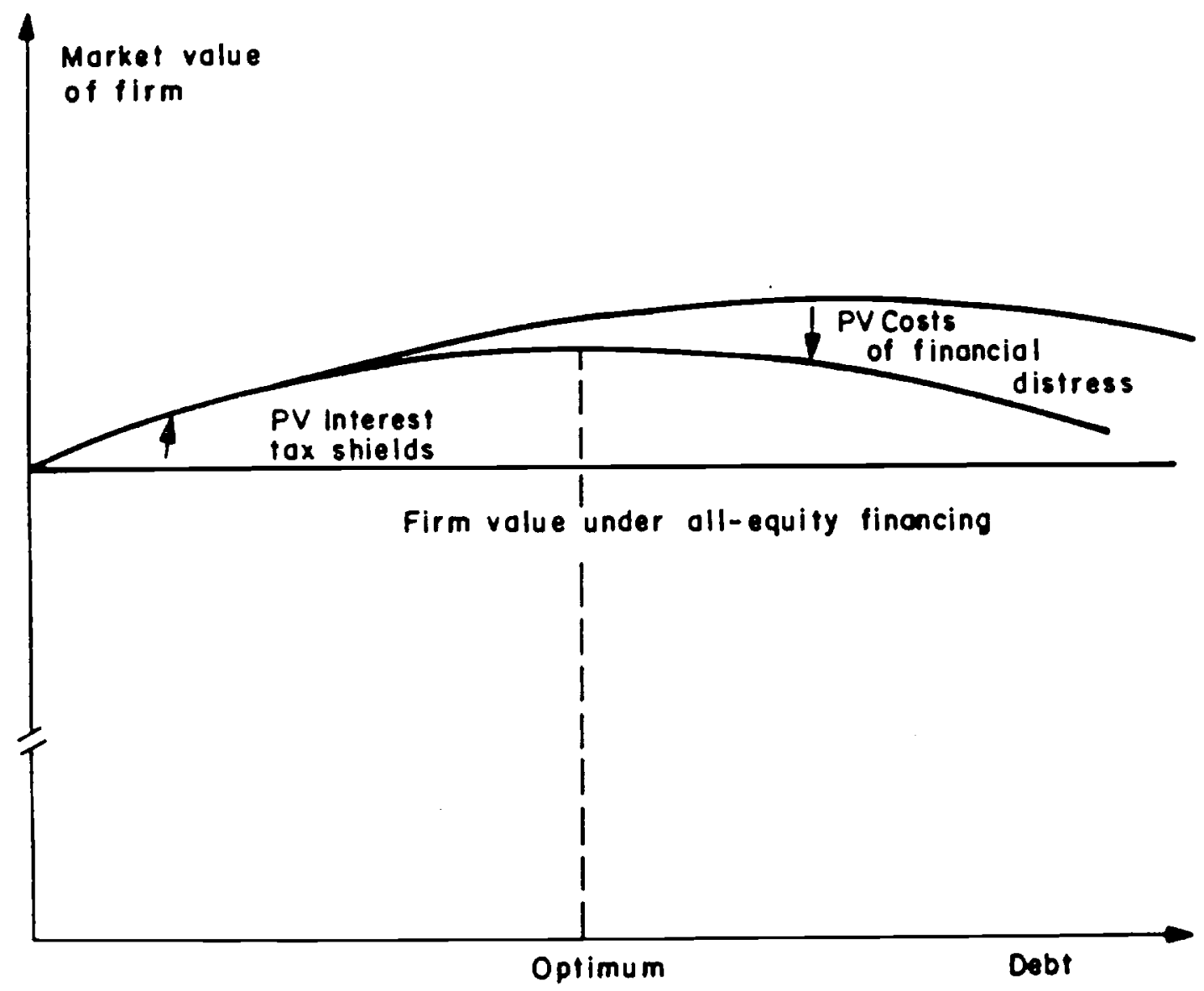




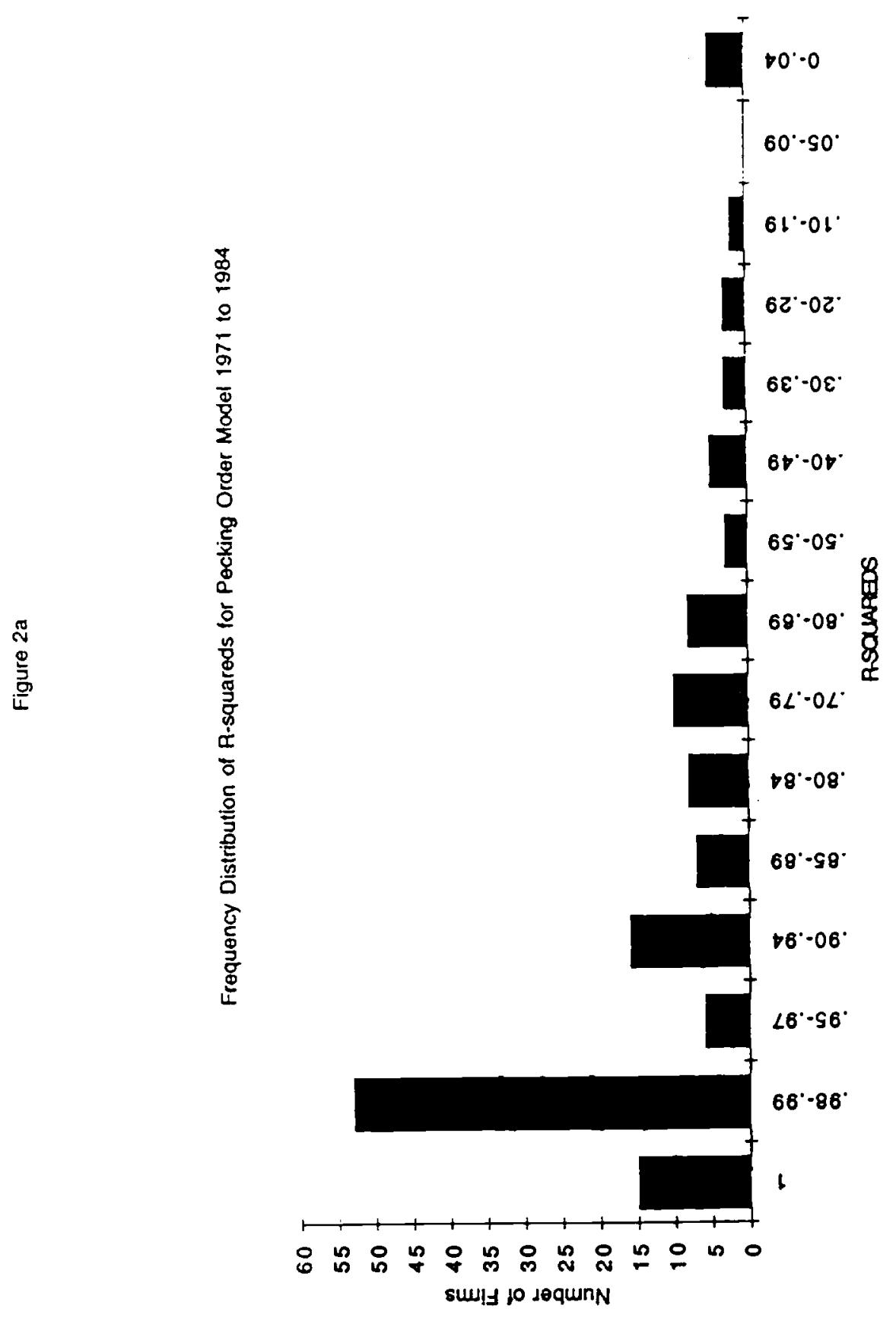

is 


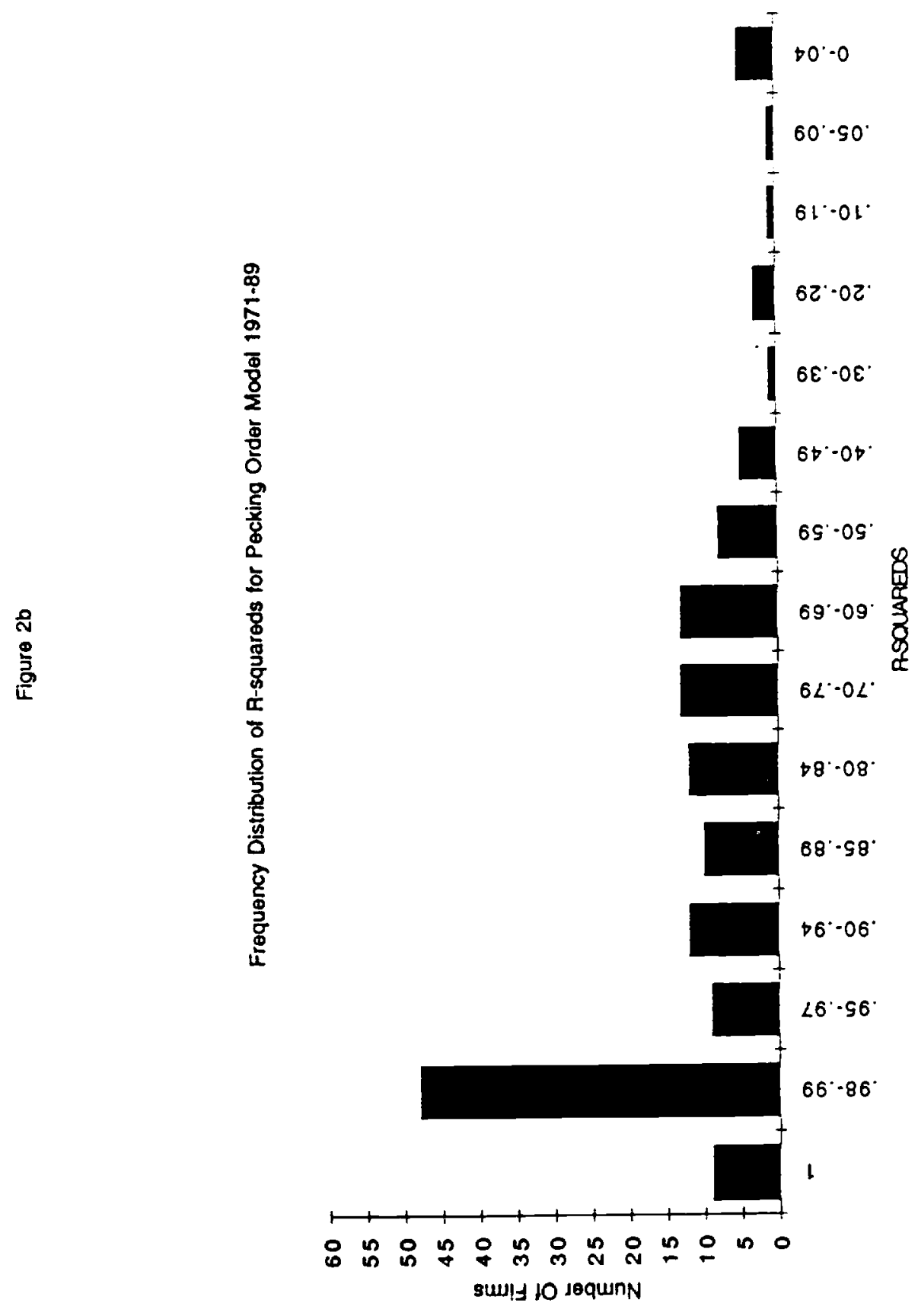

